\section{Gender differences in lung function recovery after cessation of occupational endotoxin exposure: a complex story}

\author{
Dick Heederik, Lidwien A M Smit
}

In the 30-year follow-up of the Shanghai Textile Worker Study, Lai et $a l^{1}$ show that individuals with high occupational endotoxin exposure have a more limited lung function recovery after retirement than those with lower organic dust exposures. The results also suggest that lung function improves less in men than in women. These results are of interest for several reasons: they tell us about the underlying mechanisms of endotoxin-related health effects, they give information about the prognosis of formerly diseased workers, and gender differences have not been studied extensively in the work environment.

Endotoxin exposure in the studied population was the result of occupational cotton dust exposure. Cotton workers were compared with silk workers, who had a very low endotoxin exposure. Studies of cotton workers, livestock farmers and animal feed workers have shown an accelerated decline in lung function related to endotoxin exposure level. ${ }^{2-4}$ Because most studies are crosssectional and follow-up duration is limited in most longitudinal studies, few have the ability to show whether there is sustained improvement after exposure cessation.

An accelerated decline in lung function is considered the hallmark of chronic obstructive pulmonary disease. The earliest observations that exposure cessation is associated with an improvement after a period of accelerated lung function decline probably comes from the classic study of Fletcher et $a l,{ }^{5}$ 'The Natural History of Chronic Bronchitis and Emphysema', published in 1976. This study, which evaluated working men in England over an 8-year period, showed that smoking cessation was associated with an improvement in lung function

IRAS Division Environmental Epidemiology, University of Utrecht, Utrecht, The Netherlands

Correspondence to Dr Dick Heederik, IRAS Division Environmental Epidemiology, University of Utrecht, Utrecht, PO Box 80178, 3508 TD, The Netherlands; d.heederik@uu.nl later on. This was an important observation at the time because it indicated that lung function decline is not progressive after smoking cessation and smoking cessation changes the course of disease. ${ }^{6}$ The observations by Lai et al for high endotoxin exposed individuals are especially relevant for those with low lung function. Removal from exposure may improve their prognosis and these results emphasise that surveillance by repeated lung function measurements might be of importance, in particular for hyperresponders to endotoxin, who may be at increased risk for an even faster decline in lung function. 78

This long-running cohort is ideal to study differential effects of gender because of the relatively balanced composition: more than $50 \%$ of the population consisted of women, at baseline and at the end of follow-up. Contact with the authors made clear that the cumulative endotoxin exposure distributions for men and women were very similar and strongly overlapping. This makes it unlikely that a differential effect of endotoxin exposure cessation in women and men is caused by a difference in exposure. This is an important strength of the study, and also unique. We seldom have populations of men and women with more or less similar occupational exposure to chemical and biological agents that allows the study of gender differences.

However, there are a few caveats. First, exposure assessment was based on area measurements. Differences in exposure levels between male and female workers might have been more pronounced if personal sampling was used, for instance, because different tasks are being performed by men and women. Second, it is unknown which occupational exposure is responsible for lung function decline and recovery after retirement among silk workers. Remarkably, in silk workers, a similar gender effect on lung function improvement was observed. Third, it can be challenged whether the effects of gender and smoking can be separated accurately given the low numbers of non- smoking men and smoking women. At the end of follow-up, approximately $80 \%$ of the men and $4 \%$ of all women were lifetime smokers. This essentially means that non-smoking women have been compared to predominantly smoking men. The question is whether the smoking effect can be estimated reliably for both sexes and whether the study allows an accurate comparison of non-smoking women with non-smoking men. In particular, the small size of the group of smoking women does not allow estimation of a smoking effect in women with sufficient precision. In their publication with 25 years of follow-up, the authors also concluded that the power was too limited to describe separate effects for smoking women. ${ }^{9}$ In that analysis-using less flexible models-a small but statistically significant difference in exposure cessation related lung function improvement was found in nonsmoking women compared to nonsmoking men (14.6 mL/year) observed over a 5-year period since exposure cessation.

Despite the fact that the evidence of a differential response of men and women to occupational endotoxin exposure cessation from the present publication should be interpreted with caution; there is certainly biological plausibility to the hypothesis that gender differences might exist in response to endotoxin. It has been suggested that differences exist between men and women in inflammatory disease occurrence, and inflammatory responses can differ, in human observational studies and animal experimental studies. ${ }^{10-12}$

These publications show that the hypothesis on gender differences is of interest and deserves to be studied more intensively.

\section{Competing interests None declared.}

Provenance and peer review Commissioned; internally peer reviewed.

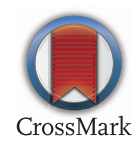

To cite Heederik D, Smit LAM. Occup Environ Med 2015;72:543-544.

Received 23 March 2015

Accepted 1 April 2015

Published Online First 28 April 2015

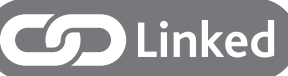

- http://dx.doi.org/10.1136/oemed-2014-102579

Occup Environ Med 2015;72:543-544.

doi:10.1136/oemed-2014-102783 


\section{Commentary}

\section{REFERENCES}

1 Lai PS, Hang JQ, Valeri L, et al. Endotoxin and gender modify lung function recovery after occupational organic dust exposure: a 30-year study. Occup Environ Med 2015;72: 546-52.

2 Bunger J, Schappler-Scheele B, Hilgers R, et al. A 5-year follow-up study on respiratory disorders and lung function in workers exposed to organic dust from composting plants. Int Arch Occup Environ Health 2007;80:306-12.

3 Post W, Heederik D, Houba R. Decline in lung function related to exposure and selection processes among workers in the grain processing and animal feed industry. Occup Environ Med 1998;55: 349-55.
4 Vogelzang PF, van der Gulden JW, Folgering $H$, et al. Endotoxin exposure as a major determinant of lung function decline in pig farmers. Am J Respir Crit Care Med 1998;157:15-18.

5 Fletcher C, Peto R, Tinker C, et al. The natural history of chronic bronchitis and emphysema. New York: Oxford University Press, 1976.

6 Rennard SI, Vestbo J. Natural histories of chronic obstructive pulmonary disease. Proc Am Thorac Soc 2008;5:878-83.

7 Kline JN, Cowden JD, Hunninghake GW, et al. Variable airway responsiveness to inhaled lipopolysaccharide. Am J Respir Crit Care Med 1999;160:297-303.

8 Smit LA, Heederik D, Doekes G, et al. Ex vivo cytokine release reflects sensitivity to occupational endotoxin exposure. Eur Respir J 2009;34:795-802.
9 Shi J, Hang JQ, Mehta AJ, et al. Long-term effects of work cessation on respiratory health of textile workers: a 25-year follow-up study. Am J Respir Crit Care Med 2010;182:200-6.

10 Casimir GJ, Lefevre N, Corazza F, et al. Sex and inflammation in respiratory diseases: a clinical viewpoint. Biol Sex Differ 2013;4:16.

11 Card JW, Carey MA, Bradbury JA, et al. Gender differences in murine airway responsiveness and lipopolysaccharide-induced inflammation. J Immunol 2006; 177:621-30.

12 Tesfaigzi Y, Rudolph K, Fischer MJ, et al. Bcl-2 mediates sex-specific differences in recovery of mice from Ips-induced signs of sickness independent of il-6. J Appl Physiol (1985) 2001;91:2182-9. 


\section{OEM}

Gender differences in lung function recovery after cessation of occupational endotoxin exposure: a complex story

Dick Heederik and Lidwien A M Smit

Occup Environ Med 2015 72: 543-544 originally published online April 28, 2015

doi: 10.1136/oemed-2014-102783

Updated information and services can be found at:

http://oem.bmj.com/content/72/8/543

These include:

References This article cites 11 articles, 5 of which you can access for free at: http://oem.bmj.com/content/72/8/543\#BIBL

Email alerting service

Receive free email alerts when new articles cite this article. Sign up in the box at the top right corner of the online article.

\section{Notes}

To request permissions go to:

http://group.bmj.com/group/rights-licensing/permissions

To order reprints go to:

http://journals.bmj.com/cgi/reprintform

To subscribe to BMJ go to:

http://group.bmj.com/subscribe/ 